\title{
ÜSTÜN ZEKÂLI OLMAK
}

ARAŞTIRMA MAKALESI

\section{Nagihan TANIK ÖNAL', Uğur BüYüK²}

1 Dr. Öğr. Üyesi, Niğde Ömer Halisdemir Üniversitesi Eğitim Fakültesi Temel Eğitim Bölümü, nagihanta@gmail.com, ORCID: 0000-0002-5926-521X.

2 Prof. Dr., Erciyes Üniversitesi Eğitim Fakültesi, ugurboyuk@gmail.com, ORCID: 0000-0002-6830-8349.

Öz: Bu araştırmada; üstün zekâlı öğrencilerin üstün zekâlı olmayan akranlarından farklı yönleri, üstün zekâlı olmanın üstünlerin hayatlarına etkisi ve üstün zekâlı olarak tanılanmak ile ilgili görüşleri incelenmiştir. Nitel araştırma yöntemi fenomenoloji deseni ile gerçekleştirilen araştırmaya on üstün zekâlı öğrenci, yedi veli ve Bilim Sanat Merkezi'nde görev yapan iki öğretmen katılmıştır. Katılımcılarla gerçekleştirilen yarı yapılandırılmış görüşmelerle toplanan veriler içerik analizi ile çözümlenmiştir. Elde edilen sonuçlar; üstün zekâlı öğrencilerin üstün zekâlı olmayan akranlarından öğrenme hızı, üst düzey düşünme becerisi, olgun ve esprili kişilikleri ile ve erken gelişim özellikleri gösterme yönleri ile ayrıldıklarını göstermektedir. Öğretmenlerine göre ise katılımcılar yoğun bir stres ve başarı baskısı yaşamaktadır. Buna paralel şekilde üstünler bu şekilde etiketlenmekten memnun olmadıklarını belirtmişlerdir. Bu sonuçlara göre üstün zekâlı öğrencilerin çevrelerindeki bireylerde üstün zekâlı öğrencilerle ilgili yanlış inanışların değiştirilmesine yönelik önlemler alınması gibi öneriler getirilebilir.

Anahtar Kelimeler: Üstün zekâlı çocuklar, veli, öğretmen, görüş, fenomenoloji 


\title{
TO BE A GIFTED CHILD
}

\begin{abstract}
:
In this study; different aspects of gifted students from their non-gifted peers, the effect of being gifted on the lives of gifted and their opinions about being diagnosed as gifted were examined. Ten gifted students, seven parents, and two teachers working in the Science and Art Center participated in the research, which was carried out with the phenomenology pattern of qualitative research method. Data collected through semi-structured interviews with participants were analyzed by content analysis. The results show that gifted students differ from their non-gifted peers in terms of learning speed, high level thinking skills, mature and humorous personalities, and aspects of early development. According to their teachers, the participants experience intense stress and success pressure. In parallel, the gifted cildren stated that they are not satisfied with being labeled in this way. According to these results, suggestions such as taking measures to change the false beliefs about gifted students in individuals around the gifted students can be made.
\end{abstract}

Keywords: Gifted children, parents, teacher, opinion, phenomeno$\log y$

\section{Giriş}

Ülkeler için yerüstü hazinesi ya da hediye olarak verilmiş çocuklar (gifted children) olarak adlandırılan üstün zekâlı çocuklar ülkeler için çok kıymetli değerlerdir. Kuşku yok ki bu pırıltılı beyinlerin mümkün olan en küçük yaşta tespit edilmeleri, tanılanmaları ve 'özel' olarak yetiştirilmeleri ülkelerin gelişmesine oldukça katkı sağlayacaktır. Bu özel eğitim, üstün zekâlı çocuklara tanınan bir ayrıcalık değil zaten onların haklarıdır. Clark (1997) da bu noktaya temas ederek üstün zekâlı öğrencilerin ihtiyaçlarına uygun bir eğitim almaları sonucunda bu öğrencilerin icatlar ve keşifler yaparak insanlığa hizmet edeceklerini, insanlığın sorunlarına akla uygun çözümler getirebileceklerini ve bilim, sanat gibi alanlarda önemli gelişmeler yaşanacağını belirtmiştir. Bu 
durumun anlaşılmasıyla özellikle son yıllarda üstün zekâlı bireylerin eğitimleri ile ilgili çalışmalar pek çok ülkede ivme kazanmıştır.

Bu bağlamda ülkemizde de özel eğitime ihtiyaç duyan çocukların eğitimini sağlamak adına Millî Eğitim Bakanlığı (MEB) tarafından Özel Eğitim, Rehberlik ve Danışma Hizmetleri Genel Müdürlüğü kurulmuş ve özel eğitime ihtiyaç duyan engel grupları ve üstün zekâlılar için ayrı şubeler oluşturulmuştur (Dönmez, 2004). Bu kapsamda üstün zekâlı çocukların eğitim ihtiyaçlarını karşılamak maksadıyla Bilim ve Sanat Merkezleri (BILSEM) açılmıştır. Üstün zekâlı öğrenciler bu merkezlerde kendilerine özgü özellikleri doğrultusunda eğitim almaları hedeflenmektedir. Bu durumda ülkemizdeki BİLSEM'lerde görev yapan öğretmenlerin üstün zekâlı öğrencilerin eğitiminde önemli bir pozisyonda oldukları ifade edilebilir. Öğretmenler öncelikli olarak üstün zekâlılık konusunda bilgi sahibi olmalı ve öğrencileri iyi tanımalılardır. Bu durum üstün zekâlılar için verilen eğitimin başarısını artıracaktır. Benzer şekilde MEB (2006) öğretmenlerin, öğrencilerinin fiziksel, sosyal, bilişsel, dil, duygusal, kültürel gelişimlerine ait seviyelerini, öğrenme şekillerini, güçlü ve zayıf yönlerini ayrıca ilgi ve ihtiyaçların bilmesi gerektiğini vurgulamıştır. Ancak alanyazın incelendiğinde öğretmenlerin üstün zekâlı öğrenciler ile ilgili bilgi birikimlerinin tatmin edici düzeyde olmadığı görülmektedir (Gökdere, Küçük \& Çepni, 2003; İnan, Bayındır \& Demir, 2009; Kontaş, 2009; Şahin, 2011).

Üstün zekâlı çocukların eğitimi noktasında öğretmenler kadar önemli bir diğer bileşen de çocukların aileleridir. Ailelerin çocuklarını doğdukları andan itibaren gözlemleyerek onlarla her an iç içe olmaları sebebiyle çocuklarını çok iyi tanıdıkları ve çocuklarının eğitimleri sürecinde yaşadıklarının yakın takipçisi oldukları dikkate alınarak üstün zekâlı çocukların hayatlarında anahtar bir rol oynadıkları ifade edilebilir. Çocukların ilk öğretmenleri olan anne ve babaların çocuklarının gelişim özellikleri hakkında bilgi sahibi olmaları, onların çocuklarından beklentilerini ve çocukları ile iletişimlerini etkilemesi açısindan oldukça önemlidir (İşmen Gazioğlu, 2011). Bu sebeple üstün zekâlı bir çocuğun anne ve babası olmak ayrı bir dikkat gerektirir. Çocukların üstün yeteneklerini fark etmek ve bu yetenekleri geliştirmek noktasında aileler öncelikli ve önemli bir pozisyondadır. Öte yandan maalesef ki aileler üstün zekâlı çocukların karakteristik özelliklerini tam olarak bilememekte ve ne yapmaları gerektiği konusunda çeşitli sıkıntılar yaşamaktadırlar (Moon, 2004). Bu da 
son derece tehlikeli bir durum olup üstün zekâlı çocukların potansiyellerini sergileme imkânı bulamamalarına, çatışma ve kararsızlık gibi olumsuz özelliklere sürüklenmelerine, endişe içinde olmalarına sebebiyet verebilmektedir (Campbell, 1996). Nitekim Tyler-Wood (2000) üstün zekâlı çocukların eğitimi sürecinde çocuklara en iyi koşulların sunulmasıyla ilgili ailelerin sürece dâhil olması gerektiği noktasında bir görüş birliğine varıldığını ifade eder.

Peki üstün zekâlı çocukların eğitimine nereden başlamak gerekir? Öncelikle elbette üstün zekâlı çocukların özelliklerinin iyi bilinmesinden, üstün zekâlı olmayan akranlarından farklılıklarının farkında olunmasından ve doğru bir tanılama sürecinden başlamak gerekir. Bununla birlikte üstün zekâlı tanısı konulan bireylerin üstün zekâlı olmaya ilişkin algıları ve bu tanılamanın onlara getirdikleri (ya da götürdükleri) gibi noktalar üzerinde önemle durulması gereken durumlardır. Nitekim IV. Ulusal Çocuk Kongresi'nde gerçekleştirilen Özel Yetenekli Öğrenci Çalıştayı'nda üstün zekâlı öğrencilerin; öğretmenlerinin ve ailelerinin hatta tüm sosyal çevrenin üstünlerden beklentilerinin fazla olması, bir sınıf arkadaşlarının onları geçmesi durumunda çevrelerinden olumsuz tepkiler alma, akranlarından farklı özellikleri sebebiyle onlarla uyum zorluklarıyla karşı karşıya kalma gibi sorunlar yaşadıkları belirlenmiştir. Bu sorunlara getirilen öncelikli çözüm ise ailelerin ve öğretmenlerin üstün zekâlı öğrencilerin özelliklerini iyi bilmeleri ve bu konuda eğitilmeleri olmuştur (Akbüber ve diğerleri, 2019). Ayrıca üstün zekâlı çocukların gruplandırılması ile ilgili farklı iddialar mevcuttur. Bazı araştırmacılar tarafından öğrencilerin gruplandırılmasının deyim yerindeyse etiketlenmesinin elitist ve ayrımcı bir yaklaşım olduğu bunun demokratik eğitim sürecine ters düştüğü iddia edilmektedir (Maker ve Nielson, 1996; McDaniel, 2002). Oysa bazı isimlere göre ise bir okulda tenis, basketbol gibi sporlarla uğraşıp bir okulun takımına giren ya da korosunda yer alan öğrenciler ne kadar doğalsa üstün zekâlıların gruplandırılması da o kadar doğaldır (Webb, Gore, Amend ve DeVries, 2007). Gruplama ile üstün zekâlıların eğitiminde dikkate değer bir akademik başarı sağlandığı ve bu çocukların benlik kavramlarının geliştiği (Moore, 1992), üstün zekâlı olan ve olmayan öğrenciler kendi içlerinde gruplandığında üstün olmayan öğrencilerin özgüvenlerinin yükseldiği görülmektedir (Rogers, 2002).

Bu bağlamda üstün zekâlı olmayı irdeleyen bu araştırmada; üstünlerin üstün zekâlı olmayan akranlarından farklı yönleri, üstün zekâlı olmanın üs- 
tünlerin hayatlarına etkisi ve üstün zekâlı olarak tanılanmak ile ilgili görüşleri incelenmiştir. Araştırmada cevap aranan sorular ise şunlardır:

i) Üstün zekâlı öğrencilerin, velilerinin ve BİLSEM fen bilimleri öğretmenlerinin üstün zekâlı öğrencilerin üstün zekâlı olmayan akranlarından farklılıkları ilgili görüşleri nelerdir?

ii) Üstün zekâlı öğrencilerin akranlarından farklı özellikleri hakkında üstün zekâlı öğrenciler neler düşünüyor?

iii) Üstün zekâlı olmanın hayatlarına etkisi hakkında üstün zekâlı öğrencilerin görüşleri nelerdir?

iv) Üstün zekâlı öğrencilerin üstün zekâlı olarak tanılanmak hakkındaki görüşleri nelerdir?

\section{Yöntem}

\section{Araştırmanın Deseni}

$\mathrm{Bu}$ araştırma nitel araştırma yöntemi fenomenoloji deseni ile gerçekleştirilmiştir. Nitel araştırmalar bir genellemeye ulaşmaktan çok bir durumla ilgili daha yakından ve derinlemesine anlama veya keşfetme imkânı tanıdığı için bu yöntem seçilmiştir. Bu araştırmanın deseni ise sağlam felsefi temelleri olan fenomenolojidir. Fenomenoloji farkında olunan ancak derinlemesine ve ayrıntılı bir anlayışa sahip olunmayan olgulara odaklanır (Yıldırım ve Şimşek, 2013). Araştırmada incelenen ve ulaşılmaya çalışılan öz, üstün zekâlı olmanın ne demek olduğunun açılanmasıdır.

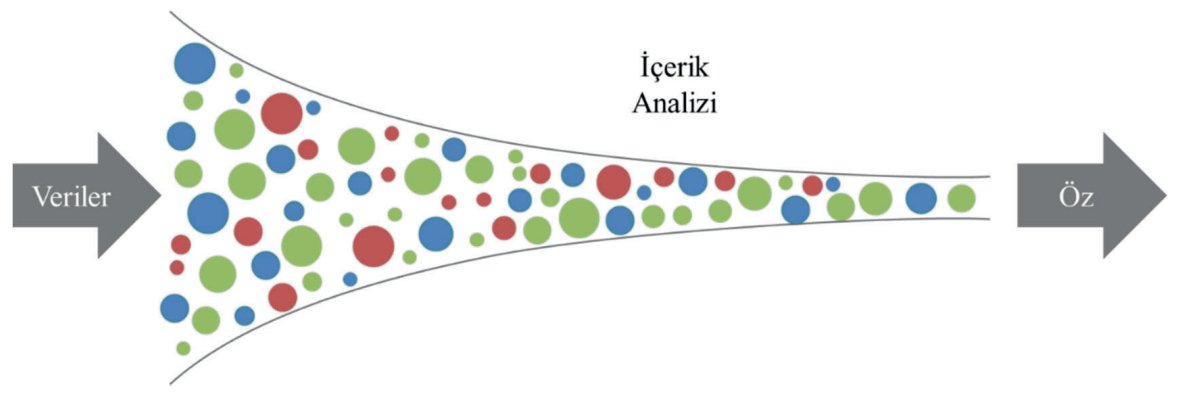

Şekil 1. Araştırmanın Deseni 


\section{Çalışma Grubu}

Bu araştırmaya İç Anadolu Bölgesi'nde yer alan bir BİLSEM'e devam eden 10 üstün zekâlı öğrenci, yedi veli ve BILLSEM'de görev yapan iki fen bilgisi öğretmeni katılmıştır. Araştırmanın katılımcıları ölçüt örnekleme esas alınarak BİLSEM Destek Eğitim Programına devam etme ölçütüne göre belirlenmiştir. Araştırmaya katılan on üstün zekâlı öğrenci 12-13 yaş aralığındadır. Ayrıca öğrencilerden altısı erkek, dördü kadın olup iki tanesi özel okulda eğitim görmektedir. Öğrencilerin velilerinden üçü araştırmaya katılmaya gönüllü olmamıştır. Velilerin yaş aralığ $34-45$ olup üçü erkek dördü kadındır. Araştırmada BİLSEM'de görev yapan fen bilgisi öğretmenleri ile çalışılmasının sebebi ise öğrencilerin devam eden fen projeleri sebebiyle bu öğretmenlerle uzun süre vakit geçirmeleri böylece daha yakın temasta bulundukları için birbirlerini daha iyi tanımalarıdır. Fen bilgisi öğretmenlerinin ikisi de erkektir. Biri yüksek lisans mezunudur.

\section{Veri Toplama Araçları}

Araştırmanın verileri katılımcılarla gerçekleştirilen yarı yapılandırılmış görüşmeler ile toplanmıştır. Bunun için görüşmeler öncesinde araştırmacılar tarafından bir yarı yapılandırılmış görüşme formu oluşturulmuş ve bu form üstün yetenekliler alanında doktora derecesine sahip üç uzmanın görüşüne sunularak onay alınmıştır. Formda beş soru yer almaktadır. Aşağıda örnek maddeler verilmiştir.

$\checkmark$ Akranlarınızdan farklı özelliklere sahip olduğunuzu düşünüyor musunuz? Cevabınız evet ise bu özellikler nelerdir? Açıklar mısınız?

$\checkmark$ Üstün zekâlı olmak hayatınızı etkiliyor mu? Nasıl etkiliyor? Açıklar misiniz?

\section{Verilerin Toplanması}

Görüşmeler, BİLSEM'de rehber öğretmenin odasında yalnızca araştırmacı ve katılımcının varlığ çekleştirilmesinin sebebi, katılımcıların kolay ulaşabilmesini ve güvenliğini sağlamaktır. Görüşmeler öncesinde katılımcılara çalışmanın amacı hakkında bilgi verilmiş ve elde edilen verilerin yalnızca bilimsel amaçlarla kullanılacağı aynı zamanda kişisel bilgilerinin de saklı tutulacağı belirtilmiştir. Görüşmeler sırasında katılımcılardan izin alınarak onayları doğrultusunda ses kayıt ciha- 
zıyla görüşmeler kaydedilmiştir. Üstün zekâlı öğrenciler ile gerçekleştirilen görüşmeler ortalama yarım saatlik bir sürede tamamlanmıştır. Veliler ve BİLSEM fen bilimleri öğretmenleri ile gerçekleştirilen görüşmeler ise ortalama 15 dakika sürmüştür. Kayıt edilen görüşmeler mümkün olan en kısa sürede transkript edilmiştir. Veriler transkript edilirken harfiyen yazılmış ve asla konuşulanlara müdahale edilmemiştir. Bununla birlikte katılımcının duraksamaları (Bekliyor, düşünüyor gibi ifadelerle), sevinç (gülüyor gibi) ve sıkıntı gibi belirtileri de deşifreye aktarılmıştır.

\section{Verilerin Analizi}

Araştırmada veri analizi sürecine başlamadan önce toplanan veriler analize hazırlanmıştır. Bu kapsamda öncelikle toplam 19 kişi ile gerçekleştirilen görüşmeler araştırmacı tarafından kelimesi kelimesine transkript edilmiştir. Katılımcıların izniyle ses kayıt cihazı ile kayıt altına alınan görüşmeler Microsoft Word dokümanı haline dönüştürüldükten sonra her bir katılımcıya kod verilmiştir. Üstün zekâlı öğrenciler için ÜZ1'den başlayarak ÜZ10'a kadar; veliler için V1'den V7'e kadar kod verilmiştir. Fen bilimleri öğretmenleri ise Ö1 ve Ö2 şeklinde kodlanmış ve veri analizine başlanmıştır. Araştırmada toplanan veriler içerik analizi ile çözümlenmiştir. İçerik analizi, nitel verileri açıklamak için veriler içerisindeki kavram ve ilişkileri kodlar ve temalar oluşturarak düzenleme ve yorumlama sürecidir (Yıldırım ve Şimşek, 2013). İki araştırmacı tarafından birbirinden bağımsız bir şekilde gerçekleştirilen özellikle birbiri yerine kullanılan veya yakın anlamlı kelime kodlamaları, görüş birliği ve görüş ayrılığı sayıları tespit edilerek değerlendirilmiştir. Bu sayede Miles \& Huberman'ın (1994) formülü ile araştırmanın kodlayıcılar arası güvenirliği de hesaplanmıştır. Bu araştırmada \%93 güvenirlik sağlanmıştır.

\section{Geçerlik ve Güvenirlik}

Araştırmanın geçerliğini sağlamak için ilk olarak araştırmacı kendi düşünce ve inanışlarını araştırmaya karıştırmamaya gayret göstermiştir (Paranteze alma). Bununla birlikte araştırmanın iç geçerliğini sağlamak için görüşme k1lavuzları üç uzmanın görüşüne sunulmuş ve gerçekleştirilen görüşmeler ses kayıt cihazında ve bilgisayarda saklanmıştır.

Araştırmanın diş geçerliğini sağlamak için ise araştırma (araştırma ortamı, katılımcıların özellikleri ve veri toplama süreçleri gibi her bir aşama) detaylı 
bir şekilde rapor edilmiştir. Bu sayede aynı adımları izleyen diğer araştırmacllar da benzer bir araştırma desenleyebilirler.

Araştırmanın iç güvenirliğini sağlamak için araştırmada ulaşılan bulgular betimlenmiş ve yorum katılmadan okuyucuya sunulmuştur. Bununla birlikte katılımcıların görüşlerinden doğrudan alıntılar verilmesi ve verilerin iki alan uzmanı tarafından analiz edilmesi de iç güvenirliği sağlamıştır.

\section{Araştırmacının Rolü}

Bu çalışmada araştırmacının ilk rolü katılımcıların rolleri hakkındaki farkındalıklarını sağlamak olmuştur. Bu nedenle araştırmanın başında katılımcılar, araştırmanın amacı ve araştırma soruları hakkında ayrıca araştırma için ne kadar önemli oldukları hususunda bilgilendirilmişlerdir. Sonrasında ise araştırma sorularına cevap aramak için katılımcılara konu ile ilgili deneyimleri sorulmuştur.

Araştırmacının bir diğer rolü ise katılımcıları sorulan sorulara cevap verme ve araştırmacıyla paylaşıma açık olma noktasında cesaretlendirmek ve katılımcıların kendilerini rahatça ifade edecekleri bir ortam yaratmak olmuştur. Görüşmeler sırasında katılımcıların görüşlerini detaylı bir şekilde açıklamalarl için kendilerini rahat hissedebilecekleri ortamlar oluşturulmuştur.

Fenomenolojik araştırma için veri analizi sürecinde araştırmacıların kendi öznel bakış açılarını araştırmadan uzak tutmaları gerekir. Moustakas (2004) tarafından paranteze alma adı verilen bu işlem kapsamında araştırmadaki başka bir rolüm ön yargılarımı yani kendi öznelliğimi araştırmadan uzak tutmak ve tamamen katılımcıların fikirlerine odaklanmak olmuştur.

\section{Bulgular}

Üstün zekâlı öğrencilerin ïstün zekâlı olmayan akranlarından farklı yönlerine ilişkin üstün zekâlı öğrenci, veli ve öğretmen görüşleri

Katılımcılara üstün zekâlıların akranlarından farklı yönleri sorulmuştur. Elde edilen verilerin analizi sonucu ulaşılan bilgiler aşağıda yer almaktadır.

Üstün Zekâlı Öğrencilerin Görüşleri

Üstün zekâlı öğrencilere “Akranlarınızdan farklı özelliklere sahip olduğunuzu düşünüyor musunuz? Cevabınız evet ise bu özellikler nelerdir? Açı- 
lar misınız?" sorusu sorulduğunda katılımcılardan ÜZ4, ÜZ5, ÜZ8 ve ÜZ9 (4/10) akranlarından farklı bir özelliğe sahip olduklarını düşünmediklerini ifade etmişlerdir. Bu katılımcılardan ÜZ5 düşüncelerini "Ben diğer arkadaşlarımdan farklı bir özelliğim olduğunu düşünmüyorum." şeklinde açıklamıştır. ÜZ8 ise benzer şekilde böyle bir farklılık algılamadığını "Yaşıtlarımdan farkım varsa da ben bilmiyorum" cümlesi ile dile getirmiştir.

Öte yandan "Evet, ben akranlarımdan farklı özellikler taşıyorum" diyen üstün zekâlı çocuklara (ÜZ1, ÜZ2, ÜZ3, ÜZ6, ÜZ7, ÜZ10) hangi yönlerinin akranlarından farklı olduğunu düşündükleri sorulmuştur. Katılımcıların verdikleri cevaplardan elde edilen bulgular Tablo 1'de yer almaktadır. Tablo 1'e göre üstünlerin akranlarından farklı bilişsel ve kişisel özellikleri olduğunu düşündükleri ifade edilebilir.

Tablo 1. Öğrencilere Göre Üstünlerin Üstün Olmayanlardan Farklılıkları

\begin{tabular}{|c|c|c|c|}
\hline Tema & Kod & Frekans & Kişiler \\
\hline \multirow{12}{*}{ Bilişsel Özellikler } & Üst Düzey Düşünme & 5 & $\begin{array}{l}\text { ÜZ4, ÜZ5, ÜZ6, ÜZ8, } \\
\text { ÜZ10 }\end{array}$ \\
\hline & $\begin{array}{l}\text { Kolay ve Hizlı } \\
\text { Öğrenme }\end{array}$ & 4 & ÜZ2, ÜZ3, ÜZ6, ÜZ7 \\
\hline & Hızlı Soru Çözme & 3 & ÜZ6, ÜZ7, ÜZ10 \\
\hline & Güçlü Görsel Hafıza & 2 & ÜZ2, ÜZ3 \\
\hline & Hazır Cevap & 2 & ÜZ5, ÜZ10 \\
\hline & Sayıları Sevme & 1 & ÜZ1 \\
\hline & Erken Yazma & 1 & ÜZ3 \\
\hline & $\begin{array}{l}\text { Uzun Cümleler } \\
\text { Kurma }\end{array}$ & 1 & ÜZ6 \\
\hline & Yüksek Not & 1 & ÜZ7 \\
\hline & Bilgili & 1 & ÜZ7 \\
\hline & Deney Yapma & 1 & ÜZ1 \\
\hline & Hayal Gücü & 1 & ÜZ7 \\
\hline \multirow{2}{*}{ Kişisel Özellikler } & Olgun & 2 & ÜZ7, ÜZ10 \\
\hline & Esprili & 1 & ÜZ5 \\
\hline
\end{tabular}


Bu bağlamda üstün zekâlı öğrencilerin kendilerinin akranlarından fark11 özelliklerini çoğunlukla bilişsel özellikler çerçevesinde açıkladıkları ifade edilebilir. Üst düzey düşünme becerisi (5/6), kolay ve hızlı öğrenme (4/6), hızlı soru çözme (3/6) ve güçlü görsel hafızaya sahip olma (2/6) üstünlerin akranlarından farklı olarak belirttikleri bilişsel özelliklerin başında gelmektedir. Örneğin; ÜZ6 ve ÜZ7 düşüncelerini sırasıyla şu şekilde açıklamışlardır:

"Ben tabi ki akranlarımdan farklıyım tesadüfen veya sanıldı̆̆̆ gibi torpille BILLSEM'i kazanmadım. Çalışkanım ama çok çalışan herkes çalışkan olabilir. Yani üstün zekâlı olmayan biri de çalışkan olabilir. Bu yüzden çalışkanlığı değil ama çok hızIn soru çözmemi yani sorular hızl cevaplayabilmemi akranlarımdan farkım olarak söyleyebilirim size. Ayrıca kolayca hızh bir biçimde öğrenebiliyorum ben arkadaşlarımdan çok daha farklı düşünüyorum nasıl desem (düşünüyor) hah ben düz mantık düşünmüyorum akıl yürütüyorum, sorguluyorum. Tüm bunlar çalı̧̧mayla elde edilemez Allah vergisi..."

"Evet, akranlarımdan farklı olduğumu düşünüyorum açıkçası. Benim notlarım çok yüksek, hızlı soru çözebiliyorum ve bariz çok daha fazla bilgiliyim ben. Öğretmen anlatıyor mesela sonra bakıyorum ben sinfftakilerden daha çok şey biliyorum. Leb demeden ben Çorumdayım. Öğrenmelerim çok hızh artı kolay oluyor. Şu zamana kadar öğrenmekte sorun yaşadığım bir konu olmamıştır. Akranlarıma göre çok daha olgun olduğumu düşünüyorum açıkçası bu konuda mütevazi olamayacă̆ım. Bazen üstün zekâlı olmayan akranlarım bana bebek gibi geliyor. Mesela onlar hiç hayal kuramıyorlar, mizirdanip duruyorlar,..."

Üstünler akranlarından bazı kişisel özellikler açısından da farklı oldukları$\mathrm{n}$ ifade etmişlerdir. Üstünler akranlarından daha olgun ve esprili olduklarını belirtmişlerdir. Örneğin, ÜZ5 “Üstün zekâlı olmayan arkadaşlarımla benim en büyük farkım farklı düşünmem onlardan daha gelişmiş düşünen bir yapım var benim. Ayrica Nasreddin Hoca gibi esprili ve hazır cevabim asla lafin altında kalmam. Yoksa herkes çalı̧̧kan olabilir derece yapabilir ama hazır cevap olmak bir fark bence. Hep söylerim espriyi zeki adam yapar zeki adam anlar. Ama şunu da belirteyim benim espriden kastım zekice olanı, saçı dökülmüşe kel deyip sonra da espri yaptım demek değil." şeklinde görüş bildirmiştir.

Velilerin Görüşleri

Üstün zekâlı çocukların akranlarından farklı özelliklerine yönelik velilerin görüşlerine de başvurulmuştur. Zira veliler hem çocuklarını doğumları itiba- 
riyle gözlemlemeye başlarlar hem de çocuklarının ilk öğretmenleridir. Bu nedenle velilere, üstün zekâlı çocuklarının üstün zekâlı olmayan yaşıtlarından farklı yönlerine ilişkin görüşleri sorulmuş ve elde edilen bulgular Tablo 2'de gösterilmiştir:

Tablo 2. Velilere Göre Üstünlerin Üstün Olmayan Akranlarından Farkl1likları

\begin{tabular}{llll}
\hline Tema & Kod & Frekans & Kişiler \\
\hline \multirow{2}{*}{ Ëken Gelişim } & Erken Konuşma & 4 & V1, V2, V6, V7 \\
& Erken Yürüme & 1 & V1 \\
& Erken Okuma & 1 & V3 \\
& Hizlı Anlama & 4 & V2, V3, V5, V6 \\
& Ayrıntıları Fark Etme & 2 & V2, V3 \\
& Farklı Sorular Sorma & 2 & V2, V4 \\
& Hizlı Kavrama & 2 & V2, V5 \\
Bilişsel Özellikler & Kuvvetli Ezber Gücü & 2 & V2, V4 \\
& Üretken & 2 & V2, V6 \\
& Güçlü Hafıza & 1 & V1 \\
& Hayal Gücü & 1 & V6 \\
& Mantıklı Düşünme & 1 & V6 \\
\hline Kinestetik/ Bedensel & Hareketli & 1 & V2 \\
& El Becerisi & 1 & V6 \\
\hline Kişisel Özellikler & İkna Becerisi Yüksek & 1 & V1 \\
& Konuşkan & 1 & V2 \\
& Meraklı & 1 & V4 \\
\hline
\end{tabular}

Veliler üstün zekâlı çocuklarının akranlarından daha erken konuşma, yürüme ve okuma gibi erken gelişim özellikleri gösterdiklerini; hayal güçlerinin gelişmiş olduğunu, mantıklı düşündükleri, çok hızlı anlayabildiklerini, hafızalarının güçlü olduğunu, ayrıntıları fark etme, hızlı kavrama ve kuvvetli ezber gücüne sahip olduklarını ifade etmişlerdir. Bu bulgular genel itibariyle 
üstünlerin görüşleri ile uyum içindedir. Öte yandan veliler, üstün zekâlı çocukların değinmediği bazı bilgilere değinmişlerdir. Veliler üstün zekâlı çocukların üstün zekâlı olmayan akranlarından hareketli ve el becerisi yüksek, ikna becerileri gelişmiş, konuşkan, meraklı ve üretken bireyler olmaları yönleriyle ayrıldıklarını düşünmektedirler. Bu konuyla ilgili bazı velilerin görüşleri aşağıdaki gibidir:

V2: "Üstün zekâlı olmayan bir yaş küçük kardeşi var mesela anlama hızları o kadar farklı ki anlatamam size. Üstün zekâlı olan çok üretken. Artı üstün zekâlı çocuk hem kardeşinden hem okuldaki sını arkadaşlarından akranları kuzenlerinden falan çok daha hareketli. Çocuğum erken anladığı gibi erken kavrar. Ayrıntıları hemen fark eder. Çocukluğundan beri böyledir. Daha bir iki aylıkken gösterdiğimiz nesneleri hatta küçücük kuru üzümü bile gözleriyle takip ederdi. Hemencecik ezberler her şeyi. Ve belki de en önemlisi sizi dehşete sürükleyecek ilginçlikte yaşından beklenmeyen sorular sorar. Mesela bir keresinde bana "Çocuklarmm robot olmasint ister miydin? Böylece hasta olmazlardı ve ölmezlerdi..." dedi (gülüyor). "

V3: "Bakın biliyorsunuzdur üstün zekâl çocuğum ikiz ve diğerinden yani üstün zekâh olmayan ikiz eşinden çok hızh öğreniyor. Çok erkenden okudu ve ayrıntılar hemen fark ederdi küçükken de şimdi de öyle. İkiz olmalarnna rağmen o kadar farklılar ki anlama hızı açısından. Tabi sınıf arkadaşları gibi diğer yaşıtlarından da farklıdır. Öğrenme hızı muazzam ve öğrenmesi kolay. Ayrıntılar onun için sıradan hemen fark eder. Aslında üstün zekâlılar için ayrıntı diye bir şey yok bence."

BILLSEM Fen Bilimleri Öğretmenlerinin Görüşleri

Üstün zekâlı öğrencilerin akranlarından farklı özelliklerine yönelik BíLSEM'de görev yapan fen bilimleri öğretmenlerinin de görüşlerine başvurulmuştur. Bu kapsamda Ö1 konu ile ilgili düşüncelerini "Hocam üstün zekâlı olan ve olmayan öğrenciler arasındaki en büyük farklılı bu öğrencilerin anlama ve kavrama hızlarıdır. Bununla birlikte üstün zekâlı öğrenciler gerçekten iyi bir takım lideridir. Üstün zekâl çocuklarla konuşurken bir yetişkinle konuşuyor gibi hissedersiniz. Üst düzey sorular sorup şaşırtıyorlar beni..." şeklinde ifade etmiştir. Ö2'nin düşünceleri ise aşağıdaki gibidir:

"Adı üstünde bu çocuklar üstün zekâll, bu nedenle akranlarından çok hizh öğrendiklerini söylememe gerek yok sanırım. Ben size daha farkl bir noktadan bahsedeyim. Üstün zekâlı çocuklar üstün zekâlı olmayan çocuklardan çok daha fazla stresli. Çünkü 
hem aileleri, hem öğretmenleri hem de çevrelerinin baskısını hissediyorlar. Yani hiç yanlıs yapma lüksleri yok gibi. Bu nedenle hata yapmaktan çok korkuyorlar. Okullarında normal zekâlı bir çocuk daha yüksek not alır veya denemelerde üstün zekâlı çocuklardan daha yüksek not alırlarsa bu ciddi bir sorun oluyor üstün zekâlı çocuk için. Önemli bir noktaya daha temas edeyim hocam bu çocuklar bazen akranlarn ile iletişim kurmakta güçlük çekiyorlar. Özellikle şımartılmış olanlar üstün zekâlı olmayan akranlarımı aşağıllayabiliyor."

Öğretmenlerin görüşlerinden üstün zekâlı öğrencilerin hızlı öğrenme gibi üst düzey bilişsel kapasiteye sahip oldukları konusunda hem fikir oldukları ve bunun zaten beklenen bir sonuç olduğunu düşündükleri ifade edilebilir. Öğretmenlerin bu görüşleri hem üstün zekâlı öğrenciler hem de üstünlerin velileri ile aynı paraleldedir. Ancak öğretmenler hem üstünlerden hem de velilerinden farklı bazı önemli noktaların altını kalın çizgilerle çizmişlerdir. Bunlar; liderlik, olgunluk, başarı baskısı kaynaklı stres ve üstün zekâlı olmayan akranları ile yaşadıkları iletişim güçlükleridir.

Öğretmenlerin değindiği bu noktalar sıradan özellikler gibi düşünülmemelidir. Gerçekten her biri büyük önem taşımaktadır. Liderlik, üstün zekâlılı̆̆ın önemli bileşenlerinden biri olması yönüyle önemli iken üstünlerin kendilerini başarı baskısı altında hissetmeleri onları olumsuz etkileyip belki de potansiyellerini geriletebileceği için önemlidir. Öğretmenlerin altını çizdiği bir diğer nokta ise üstünlerin üstün zekâlı olmayan akranları ile yaşayabildikleri iletişim güçlükleridir. Bu bulgu aslında iki noktayı işaret edebilir niteliktedir. Birincisi öğretmenler hem üstünlerin öz değerlendirmelerinden hem velilerden daha objektif cevaplar veriyor olabilir.

Üstünler ve veliler genelde üstünlerin olumlu özelliklerine yönelik cevaplar vermişlerdir. İkincisi ise üstünlerin akranlarıyla yaşadığı iletişim problemlerinin sebebi olarak öğretmenler üstünlerin akranlarını aşağılama argümanını ileri sürmüşlerdir. Bu durum üstünlerin yaşamları boyunca etkili olup onların yalnız kalmasına ve sosyal becerilerinin gerilemesine yol açabilir.

Üstün Zekâh Olmanmn Hayatlarma Etkisi Hakkında Üstün Zekâh Çocuklarm Görü̈sleri

Öğretmenin yukarıda ifade ettiği söz konusu durumun ardından üstün zekâlı öğrencilerle tekrar gerçekleştirilen görüşmede araştırmacı üstün zekâlı 
öğrencilere "Üstün zekâlı olmak hayatınızı etkiliyor mu? Nasıl etkiliyor? Açıklar mısınız?" sorusunu yöneltmiştir.

Üstün zekâlı öğrenciler genelde bu durumdan hoşnut oldukların ve hayatlarını olumlu etkilediğini düşündüklerini ifade etmişlerdir. Örneğin, ÜZ2 ve ÜZ3 üstün zekâlı olmaları sebebiyle öğretmenlerinin onları çok sevdiklerini ifade etmişlerdir. Bununla birlikte üstün zekâlı tanısı ile BiLSEM'e gitmeye hak kazanmış olmayı önemli bir şans gören öğrenciler de vardır (ÜZ1, ÜZ4, ÜZ6, ÜZ9, ÜZ10). Katılımcılardan ÜZ1, ÜZ4 ve ÜZ5 üstün zekâlı olmaktan çok mutlu olduklarını ve bunun herhangi bir olumsuzluğa sebebiyet vermediğini belirtmişlerdir. Ancak ÜZ8 bu katılımcıların aksine üstün zekâlı olmanın hayatına bir getirisi olmadığını ifade etmiştir.

Üstün zekâlı olmanın hayatlarını olumlu etkilediği kadar olumsuz da etkilediğini ifade eden ve üstün zekâlı olmanın hayatını tamamen olumsuz etkilediği düşünen katılımcıların neden böyle düşündükleri irdelendiğinde ise şu bulgulara ulaşılmıştır:

ÜZ2: “Zeki olduğum için öğretmenimin gözdesiyim. Ama arkadaşlarım beni kıskanıyor ve çekemiyor. Bana torpille BILLSEM'i kazandığımı söylüyorlar. Bu da beni üzüyor elbette."

ÜZ3: “Öğretmenlerim beni seviyor ama bazı arkadaşlarımın beni kıskandığı için dışlaması üstün zekâh olmanın kötü bir yanı. Ben ve diğer üstün zekâlı arkadaşlarım okullarında dişlanıyor.

ÜZ6: "Üstün zekâlı olup BILSEM'e gitmeye hak kazanmak çok güzel gerçekten. Burada çok güzel çalışıyoruz ilgimiz doğrultusunda şeylerle ilgileniyoruz. Arkadaşlarımızdan farkh bir zekâya sahip olduğumuz için farkh bir okula gitmek bizim hakkımız. Ama gelin görün ki etrafımızdaki insanlar bize çok fazla başarı baskısı yapıyor. Bizden hep 100 almamızı ve hep ful yapmamızı bekliyorlar."

ÜZ8: “Üstün zekâh olmanın bugüne kadar bir yararını görmedim. Bu mavi gözlü olmaya benziyor. Herkes mavi göz seviyor ve imreniyor ama mavi gözlü olmak hayatta bir şansı beraberinde getirmiyor ya işte onun gibi. Aksine eğer bir şeyi başaramazsam etrafımdakiler hemen bir de üstün zekâlısın diye eleştiriyorlar beni..."

Öğretmenlerin konu ile ilgili görüşleri hatırlanırsa Ö2, bazı üstün zekâlı öğrencilerin üstün zekâlı olmayan arkadaşlarını zaman zaman aşağıladıklarını bu nedenle iletişim sıkıntısı yaşadıklarını dile getirmişti. Ancak üstünler 
tam tersi şekilde üstün zekâlı olmayan arkadaşlarının onları kıskandıklarını ve dışladıklarını iddia etmişlerdir (ÜZ2, ÜZ3). Bu durum üstünler ve öğretmenlerinin görüşleri arasında bir uyumsuzluk olduğu şeklinde düşünülebilir.

Ayrıca daha önce Ö2'nin üstün zekâlı öğrencilerin başarı baskısı altında ve bu nedenle de akranlarından daha stresli olduklarını düşündükleri belirtilmişti. Bunu destekler nitelikte üstünler ile gerçekleştirilen görüşmelerde ÜZ6, ÜZ8 ve ÜZ9 etraflarının onlardan beklentilerinin yüksek olduğunu ve bir baskı altında olduklarını ifade etmişlerdir. Bu durum üstün zekâlı tanısının 'etiketlenme' adı verilen bir olumsuzluğa sebep olduğunu işaret etmektedir.

Üstün Zekâlı Öğrencilerin Üstün Zekâh Olarak Tanılanmak (Etiketlenmek) Hakkındaki Görüşleri

Araştırmacı üstün zekâlı öğrencilere "Üstün zekâlı olduğunuzun diğer bireyler tarafindan bilinmesini tercih eder misiniz? Neden böyle düşünüyorsunuz?" sorusunu yöneltmiştir. Katılımcıların cevapları ise oldukça dikkat çekicidir. Üstünlerden yalnızca ikisi (ÜZ2, ÜZ3) üstün zekâlı olduğunun çevresi tarafından bilinmesini istediğini dile getirmiş ve bu görüşlerini özel olmaktan mutluluk duydukları ifadesi ile gerekçelendirmişlerdir. Ü9 ve ÜZ10 ise bu durumun bazen iyi bazen kötü olduğunu yani cevaplarının hem evet hem hayır olduğunu belirtmişlerdir. Bu iki katılımcının konu ile ilgili görüşleri sırasıyla şu şekildedir:

ÜZ9:"Ben bu sorunuza hem evet hem hayır şeklinde cevap verme hakkımı kullanmak isterim. Evet, çünkü başta ailem olmak üzere etrafımdaki kişilerin üstün zekâlı olduğum için benimle gurur duymaları hoşuma gidiyor. Ama hem de hayır çünkü üstün zekâl olmayan arkadaşlarımı üzülüyor. Onlarm üzülmesini istemiyorum. Sanki hava atıyormuşuz gibi oluyor bu beni rahatsız ediyor."

ÜZ10: "Hocam bu bize Allah'ın bir lütfu bu yüzden mutluyum tabi ama bizimle gurur duyulması için tabi bilinmemiz gerekir. Ama bize ayrım yapılmasını da istemiyorum. Arkadaşlarımızdan üstün tutulmak istemediŭim için hayır diyorum."

Diğer katılımcıları ise üstün zekâlı olduklarının çevrede bilinmemesini tercih ettiklerini belirtmişlerdir (ÜZ1, ÜZ4, ÜZ5,ÜZ6, ÜZ7, ÜZ8). Bu durumun sebebi sorulduğunda ise ÜZ6, ÜZ8 ve ÜZ9 bir şeyi başaramadıklarında kınanmak istemedikleri şeklinde bir açıklamada bulunmuşlardır. ÜZ1 ise görüşlerini "Ben üstün zekâlı olduğumu etraf bilsin istemiyorum açıkçası. Bu sadece 
beni ve diğer üstün zekâh arkadaşlarımı ilgilendiren bir şey. Etrafımızın bilmesi bize ne katkı sağlayacak ki..." cümleleri ile açıklamıştır.

Bu bağlamda araştırmaya katılan üstün zekâlı çocukların üstün zekâlı olmaktan BİLSEM'e gittikleri için ve öğretmenleri tarafından sevildikleri için mutlu oldukları ifade edilebilir. Ancak katılımcıların sözlerinden, üstün zekâlı oldukları çevresindekiler tarafından bilindiğinde başarı baskısı veya arkadaşları tarafından dışlanma, kıskanılma gibi durumlar oluşabildiği için üstün zekâlı katılımcıların etiketlenmekten hoşnut olmadıkları anlaşılmaktadır.

\section{Tartışma, Sonuç ve Öneriler}

\section{Tartışma}

Üstün Zekâlı Çocukların Üstün Zekâlı Olmayan Akranlarından Farklı Özellikleri

Üstün zekâlı bireylerin toplumun yalnızca \%2'sini oluşturduğuna inanılmaktadır. Dolayısıyla bu küçük ancak kendi içinde bile büyük farklılar gösteren grubu yani üstün zekâlıları daha iyi anlamak için üstün zekâlı olmayan akranlarından farklı özelliklerini bilmek onların daha iyi anlaşılmasını sağlayabilir. Bu düşünce 1şığında söz konusu durum incelendiğinde, üstün zekâlı çocukların üstün zekâlı olmayan akranlarından önemli farklılıklar taşıdıkları tespit edilmiştir.

Araştırmaya katılan üstün zekâlı öğrenciler, akranlarından kolay ve hızlı öğrenme, hızlı soru çözme ve güçlü bir görsel hafızaya sahip olma yönleriyle farklı olduklarını bildirmişlerdir. Üstün zekâlı çocukların bilişsel yeterlikler açısından kendilerini akranlarından önde olarak düşündükleri ifade edilebilir. Araştırmada elde edilen bu sonuç ilgili alanyazın ile aynı doğrultudadır. Çünkü alanyazında üstün zekâlı çocukların doğuştan muazzam bir bilişsel yapıya ve üst düzey düşünme becerilerine sahip oldukları ifade edilmektedir (Sak, 2014).

Veliler ise üstün zekâlı çocuklarının akranlarından daha erken konuştuklarını, yürüdüklerini ve okuduklarını belirtmişlerdir. Bununla birlikte velilere göre üstün zekâlı çocuklar; çok hızlı anlarlar, mantıklı düşünürler, hayal güçleri gelişmiştir, hafızaları güçlüdür, hızlı kavrarlar ve ezber yetenekleri çok güçlüdür. 
Öğretmenlere göre ise üstün zekâlı çocuklar üst düzey bilişsel kapasiteye sahiptirler. Bununla birlikte öğretmenler, üstün zekâlıların akranlarından daha olgun, lider vasıflı ve başarı baskısı altında oldukları için stresli bireyler olduklarını ayrıca üstün zekâlı olmayan akranları ile zaman zaman iletişim sorunları yaşadıklarını dile getirmişlerdir.

Elde edilen tüm verilere bakıldığında, üstün zekâlı çocukların akranlarından farklı zihinsel, sosyal, fiziksel ve kişilik özellikleri gösterdikleri ifade edilebilir. İlgili alanyazında da bu sonucu destekler şekilde üstün zekâlı bireylerin üstün zekâlı olmayan akranlarından daha farklı zihinsel, sosyal, kişilik ve fiziksel özellikler taşıdıkları görülmektedir (Akarsu, 2001; Chan, 2000; Davasligil, 2004; Feldhusen, 2005; Silverman, 2011; Van Tassel-Baska, 1998; Yakmaci-Güzel, 2002).

\section{Üstün Zekâlı Olmanın Üstün Zekâlı Çocukların Hayatlarına Etkisi}

Üstün zekâlı öğrencilerin büyük çoğunluğu üstün zekâlı olmanın hayatlarını olumlu yönde etkilediği kanısındadır. Kunkel, Chapa, Patterson ve Walling'in (1995) araştırmalarının sonucu bu bulguyu desteklemektedir. Söz konusu araştırmada üstün zekâlı çocukların üstün zekâlı olmak konusunda olumlu düşündükleri ve çoğunluğunun bunu bir başarı olarak açıkladıkları gözlenmiştir. Öte yandan üstün zekâlı olmanın bazı zamanlarda bir olumsuzluk halini de beraberinde getirdiğini ya da tamamen olumsuz bir durum olduğunu düşünen az sayıda üstün zekâlı katılımcı da mevcuttur. İlave olarak, bazı katılımcılar üstün zekâlı olmayan akranlarının kendilerini kıskandığını bu nedenle dışlandıklarını ve üstün zekâlı oldukları için her daim başarı baskısı altında olduklarını bildirmişlerdir. Üstün zekâlı çocukların BİLSEM fen bilimleri öğretmenleri ise üstünlerin başarı baskısı altında oldukları noktasında üstünlerle aynı paralelde düşünmektedir. Ancak öğretmenler üstünlerin üstün zekâlı olmayan akranlarını aşağıladıklarını ve aralarındaki iletişim probleminin sebebinin bundan kaynaklandığını düşünmektedir. Bu sonuçlar Öpengin ve Sak (2012) tarafından gerçekleştirilen araştırmanın sonuçları ile örtüşmektedir. Öpengin ve Sak, üstün zekâlı çocukların arkadaşları arasında kendisini yalnız hissedebildiğini, zayıf yönleriyle dalga geçilmesinden ve başka çocuklarla kıyaslanmaktan rahatsız olduklarını belirtmişlerdir. Mevcut araştırma ile paralellik gösteren bir araştırmada Kerr, Colangelo ve Gaeth (1988) tarafından gerçekleştirilmiştir. Araştırmacılar çalışmalarında üstün 
zekâlıların üstün zekâlılığı kişisel gelişimleri ve eğitimleri bağlamında olumlu ama sosyal ilişkiler bağlamında olumsuz olarak değerlendirdiklerini tespit etmişlerdir.

Üstün Zekâlı Öğrencilerin Üstün Zekâlı Şeklinde Tanılanmak (Etiketlenmek) Hakkındaki Görüşleri

Araştırmada elde edilen verilerin analizi sonucunda, üstün zekâlı çocukların çoğunluğunun, üstün zekâlı tanısı konularak bu şekilde etiketlenmiş olmaktan mutlu olmadıkları bulgusuna ulaşılmıştır. Katılımcılar, üstün zekâlı oldukları için bir şeyi başaramadıklarında kınanma kaygısı yaşamaktadırlar. Bununla birlikte bazı üstünler, arkadaşları ile arasında ayrım yapılmasını istemediği için üstün olmasının bilinmesini istemediğini ve üstün olmasının kendisinden başka diğer insanları ilgilendirmediği düşünmektedir. Ataman (2014), üstün zekâlı çocukların etiketlenmesini üstünler için bir sınırlılık olarak nitelendirmiştir. Etiketlenme, aile ve toplumun üstün zekâlı çocuklara yönelik tutum ve davranışlarını değiştirebilmektedir. Bu değişiklikler üstün zekâlı çocukların daima başarılı ve kusursuz olmaları gibi beklentiler şeklinde olup üstünlere zarar verebilecek boyutlara ulaşabilmektedir. Bu noktaya dikkat çeken Davaslıgil (2015), üstün zekâlıların sahip oldukları olağanüstü kapasitelerinin toplumda beklenti oluşturduğunu bu beklentilerin üstün zekâlılara yansımasının ise baskı şeklinde olduğunu ifade etmiştir. Benzer şekilde Robinson (1985) üstün zekâlılığın sonuçta diğer insanlardan bir farklılık olduğunu ve üstün zekâlı çocuklar bu farklılığı kabullenmesi noktasında zorluklar yaşanabildiğini vurgulamakta ve çevrenin beklentilerinin de çocukları olumsuz etkilediğini belirtmektedir. Sak (2011) ise araştırması sonucu üstün zekâlı etiketinin olumlu ve olumsuz etkileri olduğuna dikkat çekmiştir. Bu araştırmada üstün zekâlı etiketinin olumlu etkileri; özgüven artışı, olumlu çevresel beklentilerin oluşması ve toplumsal katkının artışı şeklinde açıklanmıştır. Etiketin olumsuz etkileri de sosyal ortamda dişlanma, özgüvenin gerçek dişı artışı, saygınlık kaygısı, aşırı çevresel beklenti ve yetişkin çocuk davranışları gelişme riski olarak sıralanmıştır.

\section{Sonuçlar}

1. Üstün zekâlı öğrenciler üstün zekâlı olmayan akranlarından öğrenme hızı, üst düzey düşünme becerisi, olgun ve esprili kişilikleri ile ayrıldıkları görüşüne sahiptirler. 
2. Üstün zekâlı çocukların velileri çocuklarından erken yürüme, erken konuşma gibi erken gelişim özellikleri gözlediklerini vurgulamışlardır.

3. Üstün zekâlı öğrencilerin BİLSEM fen bilimleri öğretmenleri bu çocukların yoğun bir stres ve başarı baskısı altında olduklarını savunmaktadır.

4. Üstün zekâlı çocuklar, kendi içlerinde üstün zekâlı olmaktan mutlu ve memnun olmakla birlikte sosyal ortamlarında üstün zekâlı olmayan akranları tarafından zaman zaman kıskanılıp dışlandıklarını düşündükleri için üstün zekâlı olduklarının çevrelerinde bilinmesini istememektedirler.

\section{Sinırlılıklar}

Bu nitel araştırma ulaşılan sonuçları bütün üstün zekâlı öğrencilere, velilere ve fen bilimleri öğretmenlerine genellemek amacıyla gerçekleştirilmemiştir. Araştırmada ilk olarak, üstün zekâlı öğrencilerin velilerinden üç tanesinin araştırmaya katılmak istememesi araştırmanın sınırlılıklarından biri olmuştur. Araştırmanın bir diğer sınırlılığı ise veri toplama araçları ile ilgilidir. Araştırmada veri çeşitlemesi gerçekleştirmek için görüşmelerin yanı sıra gözlem ve doküman analizi teknikleri de kullanılmak istenmiş ancak gerçekleştirilememiştir. Çünkü üstün zekâlı öğrenciler ile ilgili dokümanların gizli tutulması doküman analizinde zengin veri toplanmasına engel olmuştur. Benzer şekilde BILLSEM'lerde sınıf uygulamasının olmaması sebebiyle burada her bir öğrenci ayrı ayrı çok detaylı bir şekilde gözlemlenememiştir. Öğrencilerin devam ettikleri okullarda birbirinden farklı olduğu için araştırmacı okullarda da ayrıntılı gözlem imkânı bulamamıştır.

\section{Öneriler}

1. Üstün zekâlı öğrencilerin çevresindeki bireylerde üstün zekâlı öğrencilerle ilgili yanlış inanışların değiştirilmesine yönelik önlemler alınmalıdır. Bu sayede üstün zekâlı çocuklar üzerindeki başarı baskısı dolayısıyla da yoğun olarak maruz kaldıkları stres ve endişe azaltılabilir.

2. Üstün zekâlı çocukların çevresindeki kişiler üstünlerin üstün zekâlı olmayan akranları ile yaşayabileceği sorunlar hakkında bilgilendirilmeli ve bu duruma yönelik önlemler alınması sağlanırsa üstünler sosyal çevrelerinde kendilerini daha rahat hissedebilirler. 
3. Araştırmada elde edilen sonuçlar gösteriyor ki üstün zekâlı çocuklar çoğunlukla çevrelerindeki kişiler tarafından üstün zekâlı olduklarının bilinmesini istememektedir. Toplumlar için hediye olarak nitelendirilen bu çocukların gizli kalmak istemeleri tam bir paradokstur. Bu paradoks üstün zekâlı çocuklarla ilgili bazı şeylerin eksik ya da yanlış yapıldığının işareti gibidir. Dolayısıyla bu durum dikkate alınarak öğretmenlerin, ailelerin ve aslında toplumun her bir üyesinin üstün zekâlı çocuklar ve onlara davranış şekilleri hakkında doğru bilgilendirilmesi önemlidir.

\section{Kaynaklar}

AKARSU, F. (2001). Üstün yetenekli çocuklar, aileleri ve sorunları. Ankara: Eduser Yayınları.

AKBÜBER, B.A., Erdik, E., Güney, H., Çimşitoğlu, G.G. ve Akbüber, C. (2019). Bilim ve Sanat Merkezlerinde özel yetenekli öğrencilerin sorunlarının değerlendirilmesinde bir yöntem önerisi “Özel Yetenekli Öğrenci Çalıştayı”. Üstün Zekâlılar Eğitimi ve Yaratıcılık Dergisi, 6(1), 22-39.

ATAMAN (2014), Ataman, A. (2004). Üstün zekâl ve üstün yetenekli çocuklar. İstanbul: Birinci Türkiye Üstün Yetenekli Çocuklar Kongresi Makaleler Kitabı.

CAMPBELL, L. (1996) . Teaching \& learning through multiple inteliigences. Needham Heights, Massachusetts: A Simon \& Schuster Company.

CHAN, D. W. (2000). Exploring identification procedures of gifted students by teacher ratings: Parent ratings and student self-reports in Hong Kong. High Ability Studies, 11, 69-82.

CLARK, B. (1997). Social ideologies and gifted education in today's schools. Peabody Journal of Education, 72(3), 81-100.

DAVASLIGIL, Ü. (2004). Durum Tespit Komisyonu ön raporu. İstanbul: Çocuk Vakfı yayınları.

DAVASLIGIL, Ü. (2015). Türkiye'de Üstün Zekâlı ve Yetenekli Çocukların Eğitimi İle İlgili Bir Model Geliştirme Projesi. http:/ / www.tuzyeksav.org.tr/wp-content/ uploads/2015/09/davasligil-umit-turkiyede-ustun-zek\%C3\%A2li-ve-yetenekli-cocuklarin-egitimi-ile-ilgili-bir-model-gelistirme-projesi.pdf adresinden 28.01.2016 tarihinde indirilmiştir.

DÖNMEZ, N. (2004). Bilim Sanat Merkezlerinin kurulusu ve işleyişinde yapılması gereken düzenlemeler. İstanbul: Çocuk Vakfı Yayınları. 


\section{MİLÎ EĞİTIM • Cilt: $49 \bullet$ Say1: 228, (153-174)}

FELDHUSEN, J. F. (2005). Giftedness, talent, expertise, and creative achievement. R. J. Sternberg ve J. E. Davidson (Ed.), Conceptions of giftedness içinde (s. 64-79). New York: Cambridge University Press.

GÖKDERE, S., Küçük, M., \& Çepni, S. (2003). Gifted science education in turkey: gifted teachers' selection, perspectives and needs. Asia- Pacific Forum On Science Learning and Teaching, 4(2).

INAN, H., Z., Bayındır N., \& Demir, S. (2009). Awareness level of teachers about the charactaristics of gifted children. Australian Journal of Basic and Applied Sciences, 3(3), 2519-2527.

İSMMEN GAZİĞLU, E. (2011). Aile yaşam döngüsü. İstanbul: Remzi Kitabevi.

KERR, B., Colangelo, N., \& Gaeth, J. (1988). Gifted adolescents' attitudes toward their giftedness. Gifted Child Quarterly, 32, 245-247.

KONTAŞ, H. (2009). Bilsem öğretmenlerinin program geliştirme ihtiyaçlarına ilişkin geliştirilen programın etkililiği. Yayınlanmamış Doktora Tezi, Hacettepe Üniversitesi, Sosyal Bilimler Enstitüsü, Ankara.

KUNKEL, M.A., Chapa, B., Patterson, G., \& Walling, D.D. (1995). The experience of giftedness: A concept map. Gifted Child Quarterly, 39, 126-134.

MAKER, C., \& Nielson, A. (1996). Curriculum development and teaching strategies for gifted learners. Austin, TX: PRO-ED.

MCDANIEL, T.R. (2002). Mainstreaming the gifted: Historical perspectives on excellence and equity. Roeper Review, 24, 112-115.

MEB. (2006). Özel Eğitim Hizmetleri Yönetmeliği. URL:http:/ / orgm.meb.gov.tr/Mevzuat/ozel_yon_SON/Ozel_Egitim_Hizmetleri_Yonetmeligi_son.pdf adresinden 20.05.2017 tarihinde indirilmiştir.

MILES, M.B., \& Huberman, A. M. (1994). Qualitative data analysis: An expanded sourcebook. (2. Bask1). London: Sage.

MOON, S. (2004). GCQ seminal articles. Socio-emotional issues, underachievement, counseling of gifted and talented students. Thousands Oaks,CA: Corwin Press.

MOORE, A. D. (1992). Gifted and talented children and youth.(Ed. L. M. Bullock). Exceptionalities in Children and Youth. Allyn and Bacon Inc. s. 420-448.

ÖPENGİN, E. ve Sak, U. (2012). Üstün zekâlı öğrencilerin bakış açısıyla üstün zekâ etiketinin öğrencilerin çeşitli algıları üzerindeki etkileri. Turkish Journal of Giftedness $\mathcal{E}$ Education, 2(1), 37-59.

ROBINSON, A. (1985). Summer institute on the gifted: Meeting the needs of the regular classroom teacher. Gifted Child Quarterly, 29(1), 20-23. 
ROGERS, K. B. (2002). Grouping the gifted and talented: Questions and answers. Roeper Review, 24(3), 103-107.

SAK, U. (2011). Üstün yetenekliler eğitim programları modeli (ÜYEP) ve sosyal geçerliği. Ĕ̆itim ve Bilim, 36(161), 213-229.

SAK, U. (2014). Üstün zekâlılar, özellikleri, tanılanmaları, eğitimleri. (4. Baskı). Ankara: Vize Yayınevi.

SILVERMAN, L., K., (2011). Characteristics of giftedness scale: Research and review of the literature. URL:http://www.gifteddevelopment.com/ adresinden 22.09.2016 tarihinde alınmıştır.

ŞAHIN, F. (2011). Okul öncesi yardımcı öğretmen adaylarına üstün zekâlı ve üstün yetenekli bireyler konusunda verilen bir eğitimin etkililiği. 21. Ulusal Özel Eğitim Kongresi, Gazimagusa-Kıbris.

TYLER-WOOD, T. L. (2000). An effective mathematics and science curriculum option for secondary gifted education. Rooper Review, 22(4), 266-269.

VAN TASSEL-BASKA, J. (1998). Characteristics and needs of talented learners. Vantassel-Baska, J. (Eds) Excellence in educating gifted and talented learners, İçinde ( $3^{\text {rd }}$ ed,173-191) Love Publishing, Colorado.

WEBB, J.T., Gore, J.L., Amend, E.R., \& DeVries, A. (2007). A parent's guide to gifted children. Tucson, Arizona: Great Potential Press.

YAKMACI-GÜZEL, B., (2002). Üstün yeteneklilerin belirlenmesinde yardımcı yeni bir yaklaşım: Dabrowski'nin aşırı duyarlılık alanları. Yayımlanmamış Doktora Tezi, İstanbul Üniversitesi Sosyal Bilimler Enstitüsü.

YILDIRIM, A. ve Şimşek, H. (2013). Sosyal bilimlerde nitel araştırma yöntemleri. Ankara: Seçkin Yayıncılık. 